\title{
QUÍCHUA E ESPANHOL NAS SALAS DE AULA NA
}

\section{ARGENTINA: UM APORTE PARA REFLETIR SOBRE AS PRÁTICAS LINGUÍSTICAS}

\author{
Romina Leonor TORANZOS (D $\boldsymbol{\Delta}$ \\ Universidade Estadual de Londrina (UEL)
}

RESUMO

Na Argentina, diferentes disciplinas têm se preocupado com aspectos referentes aos estudos das práticas educativas de alunos bolivianos e têm pesquisado, dentre outras questões, a respeito do silêncio evidenciado nesse contexto. Além das condutas relacionadas ao silêncio dos alunos, acontecem outras práticas linguísticas no interior das salas

OPEN ACCESS

EDITORES

- Miguel Oliveira, Jr. (UFAL)

- René Almeida (UFS)

AVALIADORES

- Lucas Martins (UNIR)

- Onilda Nincao (UFMS)

DATAS

- Recebido: 27/03/2021

- Aceito: 17/06/2021

- Publicado: 23/07/2021

\section{COMO CITAR}

TORANZOS, Romina Leonor (2021). Quíchua e Espanhol nas salas de aula na Argentina: um aporte para refletir sobre as práticas linguísticas. Cadernos de Linguística, v. 2, n. 2, e362. de aula que exigem o domínio do espanhol; ademais, somam-se a essa postura, muitos casos em que os docentes ignoram o fato de alguns estudantes terem uma língua indígena, neste caso o quíchua, como língua materna ou língua de herança. Levando em conta esse cenário, este trabalho visa apontar possíveis caminhos para repensar tais silêncios, que parecem estar fortemente atrelados a uma prática cultural, e também refletir sobre a importância do papel dos educadores nesse contexto intercultural. A partir das ferramentas metodológicas fornecidas pela etnografia e considerando também os norteamentos da Análise do Discurso, analisamos as entrevistas realizadas com jovens e adultos bolivianos, que retratam sua visão no que diz respeito às próprias lembranças e experiências em relação à língua, aos silêncios e aos processos de estigmatização no contexto escolar argentino. Por fim, procuramos esboçar algumas reflexões sob o aporte da Sociolinguística Educacional (BORTONI RICARDO, 2003; CYRANKA, 2014) quanto à possibilidade de ação a partir da formação dos educadores. 


\section{ABSTRACT}

In Argentina, different disciplines have been concerned with aspects referring to the study of education practices of Bolivian students and they have researched, among other issues, the silence that is evident in this type of context. In addition to this silence, other types of linguistic practices occur in the inside of the classrooms in which a certain demand of the Spanish language is required, ignoring in many cases, the fact that some students have an indigenous language, in this case Quechua, as their mother tongue or heritage language. Our research seeks to point out possible ways to rethink those silences, strongly attached to a cultural practice, and reflecting on the importance of the role of the educators in this intercultural context. From the methodologies provided by ethnography and also considering the contributions of Discourse Analysis, we present an analysis of interviews with Bolivian youths and adults, which reflect the views about their own memories and experiences in the Argentinian school context, in relation to the language, the silences and the processes of stigmatization. Finally, on the contributions of Educational Sociolinguistics (BORTONI RICARDO, 2003; CYRANKA, 2014), we outline some reflections regarding the possibilities of action from teacher training.

\section{PALAVRAS-CHAVE}

Sociolinguística Educacional; Imigração Boliviana; Bilinguismo; Estigmatização; Silenciamentos.

\section{KEYWORDS}

Educational Sociolinguistics; Bolivian Immigration; Bilingualism; Stigmatization; Silencing. 


\section{INTRODUÇÃO}

O estudo dos percalços pedagógicos dos alunos bolivianos nas escolas argentinas tem sido abordado por diferentes disciplinas. Em leituras sobre o assunto, evidencia-se a preocupação com o fracasso escolar dos membros da comunidade imigrante e os silêncios que se acham associados a esse fracasso. Nesses trabalhos, a problemática foi abordada a partir de pesquisas em diferentes escolas, utilizando metodologias como entrevistas e observações, em que se recuperam, na maioria das vezes, as vozes dos professores.

Diferentemente dessas investigações, o nosso objetivo neste estudo é o de refletir sobre as experiências prévias com relação às línguas e aos silêncios a partir da própria voz dos imigrantes bolivianos e de suas experiências em sala de aula, a fim de repensarmos a importância do papel dos educadores nesse contexto intercultural e apontar possibilidades de agir diante desse cenário.

Os enunciados que aqui analisaremos integram as respostas documentadas em um trabalho de campo que buscava conhecer o grau de bilinguismo e a situação de diglossia de duas gerações de falantes bolivianos na Argentina, bem como, aspectos referentes à transmissão da língua indígena (TORANZOS, 2014)1.

Para a coleta dos dados, servimo-nos das ferramentas da etnografia: observação participante, além de entrevistas estruturadas e semiestruturadas, considerando que a entrevista "é uma situação cara a cara, em que se encontram distintas reflexividades, mas, também, em que se produz uma nova reflexividade" (GUBER, 2001, p. 31, tradução nossa).

Neste trabalho, focaremos algumas das respostas fornecidas pelos entrevistados para as seguintes perguntas sobre as experiências de aprendizagem das línguas espanhola e quíchua nas escolas argentinas:2

1. Em qual língua você fez seus estudos e durante quanto tempo?

2. Você se lembra de ter sido proibido de falar quíchua alguma vez (na escola, no local de trabalho)?

Assim sendo, o presente trabalho foi organizado em quatro partes. No primeiro momento, introduzimos alguns aspectos relativos à imigração boliviana para a Argentina,

1 O questionário, composto por 28 perguntas, buscava investigar aspectos como o conhecimento das línguas em contato e a sua utilização segundo domínios e relações de funções, bem como, tendências atitudinais. A amostra populacional foi composta por 24 informantes, distribuídos de acordo com as variáveis: geração imigratória, sexo e nível socioeducacional.

2 Por uma questão de respeito e fidelidade aos comentários dos informantes, no corpo do texto aparecem apenas as versões originais em espanhol. A tradução desses trechos de fala para o português foi inserida nas notas de rodapé. 
seguidos de uma breve explicação sobre a configuração da xenofobia e a discriminação racial quanto aos imigrantes bolivianos. Logo após, seguindo os norteamentos da Análise do Discurso (doravante AD), apresentamos uma breve revisão de trabalhos que abordam a questão do silêncio dos alunos bolivianos, fator que possivelmente resulta no fracasso escolar, e também outros estudos sobre os silêncios de falantes de línguas indígenas, para verificar como o desconhecimento pelos professores sobre a cultura das comunidades falantes dessas línguas leva os docentes a configurar uma imagem do aluno silencioso. Seguido disso, construímos a análise a partir das falas dos próprios imigrantes, que mostram sua visão em relação à língua quíchua ${ }^{3}$, partindo de suas próprias experiências, ou das de seus filhos. Tais experiências revelam ainda os silêncios e os processos de estigmatização sofridos no contexto escolar argentino. Posteriormente, recorremos ao aporte teórico da Sociolinguística Educacional, para repensar possibilidades de ação que possam ser aplicadas desde a formação de professores. E, finalmente, apresentamos as conclusões.

\section{SOBRE A CHEGADA DOS BOLIVIANOS À ARGENTINA}

No início do século XIX, muitos bolivianos começaram a se instalar na Argentina, notadamente na região noroeste, para atuar em trabalhos sazonais, como na produção de cana-de-açúcar, do tabaco, e na coleta de frutas. A partir de 1950, a Argentina viveu uma época marcada pelo forte incremento de mão de obra de baixo custo em vários setores da economia; assim, os bolivianos começaram a se estabelecer em Buenos Aires devido à oportunidade de trabalho na construção civil.

Entre os anos 1960 e 1970, aconteceu o deslocamento dos imigrantes das conhecidas áreas extra-pampeanas até as zonas patagônicas da Argentina, uma etapa que evidenciou o crescimento do número de imigrantes ilegais. Já a partir de 1985, a migração boliviana começa a se adequar ao padrão das migrações globais: com a terceira leva, as pessoas começaram a se concentrar na área metropolitana de Buenos Aires - apesar de existir uma alta difusão de bolivianos por todo o território argentino -, formando os chamados "enclaves bolivianos" que são bairros constituídos por um grande número de famílias dessa nacionalidade. Algumas das características notórias desse grupo migratório, quando comparado, por exemplo, com outros de forte presença no país, como

3 Trata-se de uma língua disseminada durante o Império Inca. Na atualidade, situa-se na área dos Andes e é falada por mais de 6 milhões de pessoas ao longo dos seguintes países: Colômbia, Equador, Peru, Bolívia, Chile e Argentina (UNICEF y FUNPROEIB Andes, 2009). Para um estudo pormenorizado, é possível consultar o Atlas Sociolinguístico de Pueblos Indígenas en América Latina (UNICEF y FUNPROEIB Andes, 2009). 
o peruano ou paraguaio, são a conservação e a visibilização de tradições e festividades com viés religioso.

Sobre os aspectos linguísticos deste grupo, vale salientar que muitos dos bolivianos que se instalaram na Argentina apresentam o quíchua como língua materna ou língua de herança. Os dados fornecidos pela Academia do Runa Simi4 indicam que seriam "por volta de 1.400.000 irmãos e irmãs bolivianas que moram hoje na Argentina e são quechuahablantes" (OBSERVATORIO DE LOS DERECHOS DE LOS PUEBLOS INDÍGENAS Y CAMPESINOS, 2019). No que se refere ao presente trabalho, os bolivianos que concederam as entrevistas são provenientes dos departamentos de Cochabamba e Oruro. Especificamente, trata-se de imigrantes de primeira geração procedentes de departamentos bolivianos onde, de modo geral, ocorre uma situação de bilinguismo quíchua-espanhol (HENTCHEL, 2016).

No caso dos informantes imigrantes bolivianos que participaram de nossa pesquisa, desenvolvida em 2014, constatou-se que provinham de uma situação de diglossia prévia na Bolívia. Uma vez radicados na Argentina, entraram em contato com grupos e pessoas monolíngues em espanhol e por isso o quíchua - língua materna para alguns, segunda língua para outros - passou a ser utilizado apenas em alguns domínios e com determinados membros da comunidade. A situação, no caso da segunda geração, dos nascidos na Argentina, muda a depender de cada família e dos interesses por manter a língua e a comunicação com familiares que ainda moram na Bolívia (TORANZOS, 2014). Além disso, os dados obtidos demonstram uma forte oscilação na utilização de ambas as línguas para diferentes situações comunicativas.

\section{DA CONQUISTA À XENOFOBIA NA ATUALIDADE}

Para compreendermos melhor o contexto que suscita as discussões e problemáticas discutidas no decorrer deste trabalho, torna-se necessário recorrermos às ferramentas fornecidas pela Análise do Discurso (AD) para esclarecer que existem efeitos de sentido produzidos em determinadas condições culturais e históricas. E essas condições, conscientes de estarmos situados na América Latina, não podem ser pensadas deixando de fora o que, nos dizeres de Orlandi, resulta ser:

4 Na Argentina, a cada dez anos é realizado o Censo Nacional de Población y Vivienda que, dentre outras ações, permite reconhecer dados referentes à situação dos grupos de imigrantes. Devido à pandemia, a realização do censo foi suspensa, razão pela qual contamos apenas com as estatísticas efetivadas por outras instituições ou organismos. 
O princípio talvez mais forte de constituição do discurso colonial, que é o produto mais eficaz do discurso das descobertas, é reconhecer apenas o cultural e des-conhecer (apagar) o histórico, o político. Os efeitos de sentido que até hoje nos submetem ao "espírito" de colônia são os que nos negam historicidade e nos apontam como seres-culturais (singulares), a-históricos (ORLANDI, 2008, p. 19).

Após a expansão colonial europeia, mesmo que tenham transcorrido séculos desde aquele momento, há práticas que continuam vigentes, relações intersubjetivas que denotam uma forte presença da "colonialidade", entendida como "imposição do imaginário cultural europeu" (GARZÓN LÓPEZ, 2013, p. 311). Nesse sentido, trabalhos no marco dos estudos decoloniais evidenciam que a concepção ocidental, baseada na retórica da modernidade, tem apagado, negado e silenciado categorias de pensamentos, saberes e línguas presentes na nossa América. Essas ações são efetivadas com o intuito de universalizar e naturalizar uma concepção de mundo a partir de uma tradição cultural particular (GARZÓN LÓPEZ, 2013). Tal panorama suscita alguns questionamentos, norteando algumas das reflexões desenvolvidas neste trabalho: quais as formas de opressão, produto dessa colonização, que ainda se refletem nas práticas cotidianas? Como emergem esses aspectos no âmbito educacional e especificamente nas relações entre professores e alunos falantes de línguas historicamente negadas ou apagadas?

No caso do grupo que aqui nos interessa, o dos bolivianos que começaram a chegar à Argentina a partir da década de 1950, é preciso resgatar dois conceitos que irão aparecer ao longo destas páginas: trata-se da discriminação racial e a xenofobia. Sem eles é impossível compreendermos e dimensionarmos os múltiplos fatores que intervêm nas situações que serão comentadas neste texto.

Segundo Torla (1997), citado por Fleuri (2006), quando se fala de discriminação racial ou racismo, algumas pessoas afirmam que, além de existirem raças distintas, há a crença de que "certas raças são inferiores (normalmente, intelectualmente, tecnicamente) às outras; e que essa inferioridade não é social ou cultural (quer dizer adquirida), mas inata e biologicamente determinada" (TORLA, 1997 apudFLEURI, 2006). Fleuri ainda esclarece que esse tratamento discriminatório, destinado a uma pessoa ou a uma comunidade, pode ser categorizado como uma formulação ideológica, na medida em que traduz determinados juízos intencionais efetivados com o propósito de inferiorizar indivíduos procedentes de determinado grupo étnico.

Outro conceito fundamental no percurso destas páginas é a xenofobia. Segundo o Dicionário Dicio, xenofobia significa "aversão a estrangeiros; repugnância a pessoas ou coisas provenientes de países estrangeiros". Porém, devemos esclarecer que essa aversão não pode ser compreendida apenas como decorrência do mero reconhecimento (cognitivo) de que alguém ou algo possui outra nacionalidade (KOHATSU, 2019). Ainda a respeito dessa intolerância, Kohatsu explica que a xenofobia pode ser detectada por meio dos sentimentos intensos despertados pela ameaça imaginária que o estrangeiro representa; reiteradamente, esses sentimentos são caracterizados pelo medo ou ódio. $O$ autor 
acrescenta a ideia de que a rejeição ao estrangeiro parece encontrar alguma justificativa também "nas condições objetivas da realidade social, como a crise econômica, os altos índices de desemprego, a falta de recursos no país receptor" (KOHATSU, 2019, p. 68). E de fato, essas ideias efetivamente têm sido documentadas nas pesquisas (GRIMSON, 1999; PACECCA, COURTIS, 2009) sobre a realidade desse grupo de imigrantes.

Na visão de Pacecca e Courtis (2009), as autoras explicam que, historicamente, na Argentina, o imigrante boliviano foi tratado de modo diferente em comparação ao imigrante europeu, considerado em anos anteriores, um "bom migrante". Uma possível explicação para essa mudança no trato é fornecida por Grimson (1999), ao mencionar que "desde os âmbitos estatais foi se constituindo um discurso que confere aos imigrantes limítrofes a responsabilidade pelos problemas sociais, econômicos, sanitários e de segurança" (GRIMSON, 1999, p. 33, tradução nossa).

Em busca de delinear um cenário da questão discriminatória, o trabalho realizado pelas Associações de Direito Civil apresenta um panorama das percepções que distintos setores da comunidade boliviana têm sobre a discriminação que sofrem no dia a dia, e dos espaços específicos em que são vítimas de discriminação. Foram constatadas ações discriminatórias sofridas em:

- interações com particulares em espaços públicos da vida cotidiana;

- interações com particulares em espaços privados / comerciais (ao fazer uma compra, um senhor boliviano recebe um comprovante em que sua nacionalidade consta como "bolita");

- interações com funcionários / empregados em espaços administrativos (municipais, provinciais ou nacionais) (COURTIS; PACECCA, 2008).

Independentemente dos espaços de interação, a discriminação e a estigmatização estão presentes na vida desse grupo, e o âmbito escolar não constitui uma exceção. Além do mais, devemos lembrar que, desde o século XIX, na Argentina, tem-se evidenciado um processo de tentativa de homogeneização linguística ${ }^{5}$ por parte do Estado, diante das mudanças decorrentes da entrada massiva de inúmeros contingentes de imigrantes.

5 Nesse contexto, no período compreendido entre 1880-1930, a escola primária funcionou como o principal espaço para conseguir atingir a meta de "estado unicultural e unilingue" (PÉREZ, ROGIERI, 2013). 


\section{REALIDADE E ESTIGMA NA ATUALIDADE: TRABALHOS QUE ABORDAM A QUESTÃO DO SILÊNCIO}

Alguns dos trabalhos elencados neste texto derivam de disciplinas como a Sociologia, a Antropologia e a Etnografia. A escolha deles é justificada pela riqueza da análise apresentada e a relevância dos dados. Em muitos casos, aparecem nesses estudos reflexões sobre aspectos relacionados à questão do silêncio, do bilinguismo, e do contexto de vulnerabilidade em que se encontram imersos os alunos bolivianos.

Dentre esses estudos, o trabalho de Beherán (2009), realizado em escolas primárias e secundárias (equivalente ao ensino Fundamental e Médio no Brasil) de diferentes bairros da cidade de Buenos Aires, permite observar nos discursos das professoras a visão estereotipada de associação das famílias bolivianas à falta de oralidade. É interessante ressaltar um conceito salientado pela autora: a "hipervisibilização" da migração boliviana. Nessa perspectiva, a pesquisadora sugere que a disseminação massiva da representação dos bolivianos como "submissos" e "silenciosos" levaria os professores a perpetuar esses estereótipos, ações denominadas pela autora como práticas discriminatórias explícitas:

\footnotetext{
Nessas práticas costuma prevalecer o pressuposto de que as diferenças são deficiências. Mas nelas nem se tenta "imprimir" algo "novo", como acontece a partir das práticas assimilacionistas, muito pelo contrário, só conseguem discriminar explicitamente o estudante, condenando-o ao fracasso escolar e social (BEHERÁN, 2009, p. 7, tradução nossa).
}

Na pesquisa sobre as experiências educativas dos filhos de imigrantes bolivianos, realizada na província de Córdoba, situada na Argentina, Domenech (2014) verificou que, no que se refere às qualidades vinculadas aos alunos dessa nacionalidade nas respostas documentadas pelos professores, os adjetivos mais recorrentes foram "calados" e "tímidos". Esses atributos condizem com a ideia do aluno boliviano tido como respeitoso e submisso. Soma-se a isso, as dificuldades de aprendizado detectadas pelas professoras nas aulas, relacionadas principalmente a "problemas com a Línguab", em contraposição a uma suposta melhor predisposição para a disciplina Matemática. Essa última ideia se relaciona com um preconceito bastante generalizado de tendência natural dos bolivianos para o trabalho (DOMENECH, 2014)

Já nas observações realizadas por Novaro (2009), verificamos que os professores se mostram atravessados por seu sentimento de pertencimento de classe, por inumeráveis mandatos sociais e educativos. Nesse sentido, salientamos atitudes tanto de

6 Na Argentina, é nomeada como "Língua" a área de conhecimento em que se estuda o espanhol (língua oficial argentina), equivalente no Brasil à disciplina denominada como "Língua portuguesa", em que se aborda o português, língua oficial brasileira) 
assistencialismo e normalização, quanto de nacionalismo através do discurso democratizador (NOVARO, 2009, p. 58)

Novaro (2009) ainda adverte sobre a falta de reflexão por parte dos docentes a respeito do desconhecimento deles acerca dos estilos, práticas linguísticas e tradições históricas da população boliviana. Além disso, menciona um aspecto que revisaremos em nosso trabalho: a existência de "diferenças idiomáticas/linguísticas entre o espanhol falado pelas crianças e aquele que se fala na escola" (NOVARO, 2009, p. 59, tradução nossa).

A respeito dos aportes da Antropologia, Martínez (2012) comenta sobre a vergonha como atitude central resultante do tipo de relacionamento que se estabelece entre as crianças bolivianas e os professores no interior das salas de aula. A falta de diálogo ou escassa comunicação entre os pais bolivianos e seus filhos, tido como uma ideia arraigada segundo a autora, explicaria os "problemas" que acontecem quando é sugerido o trabalho com a oralidade nas propostas pedagógicas realizadas pelos docentes (MARTINEZ, 2012, p.78). Conforme a estudiosa, o fato dos alunos não se expressarem como a escola espera, leva os professores a terem uma concepção preconceituosa em relação aos discentes, derivada do desconhecimento das práticas reais no interior das famílias bolivianas.

Frente ao argumento preconceituoso embasado em uma suposta falta de diálogo entre pais e filhos bolivianos, o trabalho de Dreidemie (2010) deixa claro uma ampla variedade de práticas discursivas e eventos de que participam os bolivianos, fazendo uso do quíchua na comunicação. A autora assinala também várias questões úteis para repensar as condições da realidade do grupo boliviano, dentre elas, os condicionamentos linguísticos dessas crianças:

\footnotetext{
A análise dos modos de fala do setor da coletividade boliviana que aponta o quíchua como sua língua de herança mostra um fenômeno multidimensional no qual os processos de retração, conservação e inovação na estrutura e nos usos linguísticos vincula sua variabilidade aos mecanismos de identificação e adaptação do grupo ao espaço em que habita: um espaço de vulnerabilidade territorial, de fragmentação cultural e de memorização (DREIDEMIE, 2010, p. 344, tradução nossa).
}

Outros estudos realizados na Argentina têm abordado a noção do silêncio em comunidades de fala de línguas indígenas. Chama a atenção a similaridade da atitude relacionada ao preconceito que é demonstrado nas palavras dos docentes, neste caso a respeito dos alunos "tobas", um grupo étnico de grande importância na Argentina, que reside em províncias como Formosa, Chaco e Santa Fe, e em relação aos alunos falantes de guarani, situados na província de Corrientes.

Segundo a pesquisa de Borton (2011), que trabalhou com a comunidade toba, foi identificada a existência de um processo de silenciamento, produto de uma relação assimétrica entre as instituições educativas (a voz que é predominante) e a própria comunidade (BORTON, 2011). Em oposição a isso, o autor propõe repensar as 
representações que os docentes têm sobre os estilos comunicativos dos tobas e, particularmente, sobre o seu silêncio.

Frente às dúvidas e desconhecimento da cultura dos alunos tobas, outro argumento comum entre as professoras costuma ser o de que as dificuldades de aprendizagem surgem da situação de bilinguismo, o que geraria uma confusão na mente das crianças: o espanhol acaba sendo falado na escola e a língua toba é falada nos ambientes domésticos (HECHT, 2008). Veremos ao longo da discussão que se trata de um argumento recorrente também no caso do quíchua.

No que diz respeito às relações e problemáticas que emergem das situações educativas nas quais concorrem o espanhol e o guarani, língua indígena falada na província de Corrientes, uma das comunidades estudadas, podemos citar o trabalho realizado por Gandulfo (2007). A autora adverte sobre a complexidade evidenciada a partir da situação entre a proibição - explícita e implícita -, que existia e ainda persiste na comunidade e na província toda, e o fato de as crianças serem "silenciosas". Tudo isso contribui em "manter uma ideologia linguística que leva - paradoxalmente - a língua a ser inaudível" (GANDULFO, 2007 , p. 75, tradução nossa). Nesse contexto, foi desenvolvido um projeto entre os pesquisadores e os professores envolvidos com estudantes falantes de guarani, o que colaborou para que os professores percebessem a importância do trabalho abordando essas ideologias linguísticas, o que produziu uma mudança no modelo de interação oral proposta pelos professores aos alunos. Além disso, possibilitou outro tipo de vínculo, bem como, o aumento do interesse e do entusiasmo nas aulas por parte das crianças, o que pressupõe avanços no processo de aprendizado.

Considerando que a $A D$ intenta compreender os processos de significação que emergem das materialidades discursivas, temos observado que os discursos que definem o boliviano e, mais especificamente, o aluno boliviano, constituem processos de significação, produzindo um imaginário que estará presente nas salas de aula e terá consequências nas trajetórias desses aprendizes, refletindo tanto no seu agir cotidiano, como nos processos de ensino-aprendizagem.

No que diz respeito às formações discursivas, consoante os dizeres de Orlandi (1992), trata-se de "diferentes formulações de enunciados que se reúnem em pontos do dizer, em regiões historicamente determinadas de relações de força e de sentidos" (ORLANDI, 1992, p. 20). Lembrando que essas formações discursivas são manifestadas no discurso, podemos observar como elas são reveladas nas falas dos professores expostas neste texto. Elas refletem não apenas as impressões deles sobre os alunos bolivianos, mas também todo um discurso e uma ideologia que vai muito além da sala de aula, e que pode estar atrelada àquilo que é tido como estrangeiro, ao falante de uma língua minoritária.

Frente à complexidade das situações que podem acontecer nas práticas diárias, perguntamo-nos sobre a possibilidade desses docentes se distanciarem do lugar do 
preconceito caso tivessem conhecimento, por exemplo, das práticas comunicativas reais no interior das famílias bolivianas. Como avaliariam esses alunos que, em alguns casos, são bilíngues quíchua/espanhol, e em outros casos, são estudantes monolíngues que iniciam seu processo de aprendizado do espanhol na educação formal? A partir de quais lugares de poder e marcos simbólicos e valorativos se dá essa relação?

Por fim, é necessário esclarecer que as atitudes evidenciadas ao longo do trabalho se enquadram numa questão de poder, tal como clarifica Soares (2002) ao referir-se aos padrões culturais das classes dominantes e das dominadas. Sobre o último grupo, a autora explica:

Os padrões das classes dominadas são considerados como uma "subcultura" avaliada em comparação com a cultura dominante, isto é, com os padrões idealizados de cultura, que constituem a cultura dos grupos social e economicamente privilegiados. É assim que a diferença se transforma em deficiência, em privação, em carência. Trata-se, na verdade, de uma atitude etnocêntrica, para a qual ser diferente das classes dominantes é ser inferior (SOARES, 2002, p. 15 , grifo do autor)

\section{AS EXPERIÊNCIAS NAS ESCOLAS ARGENTINAS}

A seguir, apresentamos as vozes dos próprios imigrantes, que relatam quais as lembranças da educação no país receptor eles conservam, e quais foram suas experiências nas escolas argentinas enquanto filhos de bolivianos. Dessa forma, foi possível observar, ao longo de várias entrevistas, o que temos resumido em três grandes tópicos que permitiram aprofundar as nossas reflexões: os discursos preconcebidos sobre a coletividade boliviana que emergem na sala de aula, a noção de bilinguismo em disputa, e finalmente, a autopercepção da própria variedade. A seguir, trazemos à discussão um fragmento em que se pode observar o tipo de trato entre os colegas argentinos e os filhos de bolivianos, marcado por elementos discriminatórios sobre a coletividade boliviana na sala de aula:

\footnotetext{
Lo que pasa el quechua parece que no es una lengua, es un dialecto, es algo que se está perdiendo allá también, qué se yo para enseñar a los chicos de acá... es difícil que quieran aprender el quechua, incluso los hijos de los mismos bolivianos ignoran que son hijos de bolivianos. Conozco muchos muchachos que se tratan de bolivianos a pesar de ser ellos bolivianos, como que quieren dejar de ser bolivianos. Mi hija me decía "¿por qué no nacieron ustedes acá?”. La diferencia que le hacía, porque era morochita y mis papás también. Ella siempre venía mal, después le digo hija: "vos no tenés que hacerte problema, vos sos hija de bolivianos, no tenés que sentirte mal, dios no eligió al rubio, para Dios somos todos iguales, si te quieren bien, y si no, también”. Los que van a la escuela piensan que todos los bolivianos están trabajando en el campo y los compañeros le decían: "andá a juntar cebolla" (Inf.02, 46 anos).
}

7 "O que acontece com o quíchua, parece que ele não é uma língua, é um dialeto. É algo que se está perdendo lá também (na Bolívia). Sei lá, para ensinar aqui é difícil, porque as crianças não querem aprender o quíchua, até mesmo os filhos dos bolivianos ignoram que são filhos de bolivianos, como se quisessem deixar de o ser. Minha filha me falava: "pai, por que vocês não nasceram aqui (na Argentina)?". Ela sofria discriminação porque ela tinha uma cor de pele escura, e meus pais também. Ela sempre chegava se sentindo muito mal, depois eu falei: 
O testemunho permite verificar o quanto os traços físicos são marcadores do estigma. Além disso, existe, nas palavras deste pai que relembra um episódio vivido por sua filha, a referência aos trabalhos aos quais comumente se associa a coletividade boliviana dessa zona de Buenos Aires: o plantio de cebola ${ }^{8}$. Esses aspectos têm aparecido muitas vezes na pesquisa, como argumento para abandonar a língua quíchua, em decisões tomadas por parte da segunda geração de bolivianos. Desse modo, os falantes evitariam situações em que poderiam sofrer mais discriminação.

O bilinguismo em disputa é o segundo tópico aqui proposto. Ele refere-se à vitalidade e ao uso da língua indígena em sala de aula, o que é reprovado pelas professoras, ao ponto de chamarem os pais dos alunos para lhes pedir que troquem o uso do quíchua pelo espanhol.

\footnotetext{
En la escuela no podés hablar porque no entienden. Incluso los chiquitos no saben. La mujer de enfrente no sabía, su hija no habla castellano, ella era hablante neta de quechua. Los maestros le pidieron que le hablen los mismos padres en castellano. Con los compañeritos no se puede llevar bien, por eso la trataban de una india (Inf.16, 66 anos). ${ }^{9}$

Hasta los 13 años fui a la escuela en Bolivia y me hablaban en quechua y en español. Una vez que llegué a Bahía Blanca, las maestras convocaron a mi madre para pedirle que en el hogar me hablen en castellano, así llegaba a aprender y los otros chicos no se me burlaban (Inf.3, 25 anos). ${ }^{10}$ En la escuela me prohibieron hablar la lengua, "que no hable eso porque se lo podía enseñar a los chicos", porque antes en la escuela yo hablaba mucho en quechua, cuando iba a jugar al fútbol te hablaba todo en quechua (Inf.09, 22 anos). ${ }^{11}$
}

Os trechos apresentados nos levam a pensar que talvez aquele silêncio tantas vezes denunciado e associado aos alunos bolivianos esteja em íntima relação com a divisão monolinguismo/bilinguismo dos estudantes e suas próprias competências em ambas as línguas. Aqui, algumas perguntas surgem desta análise: frente ao desconhecimento do código que a escola exige, pode o silêncio atuar como resposta? Será que todos os alunos bolivianos, caracterizados por seus professores como silenciosos, estão em condições de responder em uma língua que não é a sua, ou em um registro que não dominam? Qual o impacto da proibição de se falar em quíchua na vida escolar dos estudantes?

\footnotetext{
"você não tem que levar em conta, você é filha de bolivianos, não tem que se sentir mal, Deus não escolheu apenas os brancos; para Deus a gente é tudo igual. Se eles gostam de você assim, tudo bem, e se não, também." As pessoas que vão à escola acham que todos os bolivianos estão trabalhando na roça, e os colegas falavam para ela: 'vai lá colher cebola'” (Inf.02, 46 anos, tradução nossa).

8 Estudos sobre este tema foram abordados por autores como De la Fuente (2010).

9 "Na escola você não pode falar quíchua porque ninguém compreende. Nem os mais novos. A mulher vizinha não sabia, sua filha não falava castelhano, ela era falante nativa de quíchua. Os professores pediram para ela falar em castelhano com os seus filhos. Com os colegas da turma, ela não tem bom relacionamento, por isso que a tratavam como uma índia" (Inf.16, 66 anos, tradução nossa).

10 "Até os 13 anos de idade eu frequentava a escola, na Bolívia, e conversavam comigo em quíchua e em espanhol. Uma vez que eu cheguei em Bahia Blanca, as professoras chamaram a minha mãe para pedir que em casa conversassem comigo em castelhano, para eu poder aprender e as outras crianças não zombarem de mim" (Inf.3, 25 anos, tradução nossa).

11 "Na escola fui proibido de falar a língua (quíchua): 'não fale assim, porque pode influenciar as outras crianças', porque antes na escola eu falava muito em quíchua, quando eu ia jogar futebol falava tudo em quíchua" (Inf.09, 22 anos, tradução nossa).
} 
Pensar no silencio e tentar refletir sobre ele e seus múltiplos sentidos nos leva às contribuições feitas pela $A D$ a esse respeito:

\begin{abstract}
Há um modo de estar em silêncio que corresponde a um modo de estar no sentido, de certa maneira, as próprias palavras transpiram silêncio. Há silêncio nas palavras; 2. o estudo do silenciamento (que já não é silêncio, mas "pôr em silêncio") nos mostra que há um processo de produção de sentidos silenciados que nos faz entender uma dimensão do não-dito absolutamente distinta da que se tem estudando sob rubrica do "implícito" (ORLANDI, 1992, p.12).
\end{abstract}

Ainda, as palavras proferidas pelos informantes nos permitem olhar com mais profundidade e refletir sobre a importância de os professores, durante sua formação, terem acesso a conhecimentos essenciais sobre as possíveis situações de bilinguismo ${ }^{12}$ (APPEL; MUYSKEN, 1996). Apresenta-se em seguida uma possível explicação para os conflitos evidenciados:

Em quase todas as comunidades bilíngues as duas (ou mais) línguas têm diferentes status. Além das línguas majoritárias, que têm prestígio e conotações socioeconômicas positivas, temos as línguas minoritárias, que costumam ser associadas a um status socioeconômico baixo [...]. São línguas, em maior ou menor grau, estigmatizadas (APPEL; MUYSKEN, 1996, p. 89, tradução nossa).

Junto a isso, a noção apontada por Bourdieu (1985) serve para entendermos a disputa que ocorre na sala de aula e que é vivenciada por nossos informantes: abandonar uma língua que não é permitida na escola. Qual o valor do quíchua para a escola? Como se valora o espanhol nesse âmbito? Segundo Bourdieu (1985), no "mercado linguístico", as línguas apresentam diferenças quanto ao seu valor. Assim, apresentar e dominar as diferentes competências em uma determinada língua equivale a possuir um determinado capital linguístico que pode possibilitar o acesso a outros bens.

O último dos tópicos propostos permite falar da autopercepção de uma das informantes. Ela se reconhece como usuária de uma variedade com menor prestígio, o que provavelmente serviu para o seu fracasso na área de Língua espanhola:

Yo sí hablo mal [el español]. Desde chiquita Lengua [materia curricular] me la llevo desde que existió Lengua en Bolivia y me corrigen. No sé por qué. Cualquier palabra me sale cualquier cosa, lo pronuncio mal; para escribirlo no, para hablarlo. Yo si hablo parezco bruta, y me dicen "no, no se habla así (Inf. 18, 22 anos).13

Nessa lembrança da experiência no ensino médio, a visão da informante está condicionada pelo olhar do outro, que determina o que está certo e o que está errado. Um

12 Lembramos que, em relação aos graus de bilinguismo, convém destacar a importância dos aportes realizados por Rubin (1968), reiteradamente referido até a atualidade. A autora apresenta a seguinte classificação: os bilingues coordenados (pessoas que compreendem e falam "muito bem ou bem" ambas as línguas), os bilingues subordinados (que compreendem, mas sabem falar só "um pouco") e os bilingues incipientes (que não sabem falar uma das duas línguas, embora as compreendam "bem").

13 "Eu falo mal [o espanhol]. Desde que eu era criança, em Língua [matéria curricular] eu reprovo desde que existe essa disciplina na Bolívia e me corrigem. Não sei por quê. Qualquer palavra soa como qualquer coisa, pronuncio de um jeito errado; para escrever não, mas sim, para falar. Eu, se falo, pareço burra, e me dizem: 'não se fala assim"' (Inf. 18, 22 anos, tradução nossa). 
possível silêncio pode ter sido a resposta dessa aluna, que se sente incapaz de falar corretamente a variedade do espanhol que a escola exige por apresentar o quíchua como sua língua materna, e por ter aprendido a falar o espanhol apenas no início da educação formal. Tal cenário pode ser resultado do preconceito linguístico que circula nas salas de aula, lembrando que muitas atitudes estão relacionadas aos estereótipos que todos os falantes elaboram sobre sua própria língua e a respeito da língua dos outros, de forma que essas classificações advindas do senso comum são colocadas em uma escala de valores (CALVET, 2002). Ainda, podemos perceber o que conhecemos como insegurança linguística, que surge "quando os falantes consideram seu modo de falar pouco valorizado e têm em mente outro modelo, mais prestigioso, mas que não praticam” (CALVET, 2002, p.72).

Retomando a ideia do parágrafo anterior sobre os modelos prestigiados que se impõem ao falarmos determinadas línguas ou variedades linguísticas, Orlandi (1984) questiona-se, em um texto sobre educação indígena, sobre o que acontece com a concepção da linguagem quando a alfabetização de alunos pertencentes a comunidades indígenas fica sob a responsabilidade de professores brancos. A própria autora explica:

Um outro fator importante, e que é constitutivo do processo de aprendizagem, é que, na situação de contato entre culturas diferentes, a relação entre elas é marcada, isto é, há uma cultura que é dominante e a outra dominada. Esses aspectos, e outros de cunho social, atravessam os processos de aprendizagem, mas nem sempre são levados em conta (ORLANDI, 1984, p. 26).

\section{APORTES PARA REFLETIR SOBRE AS PROBLEMÁTICAS APRESENTADAS}

Vivemos em uma época em que se multiplicam os contatos linguísticos (NARVAJA DE ARNOUX; BEIN, 2015) e novas estratégias de ensino são necessárias para enfrentar esses novos desafios. Embora se possam reconhecer os esforços efetuados pelo Estado em relação às línguas indígenas, como o programa de Educação Intercultural Bilíngue EIB ${ }^{14}$, pesquisadores como Hecht (2015), que apresenta uma trajetória no estudo da EIB com diferentes comunidades da Argentina, explica que existe uma redução dos destinatários da EIB voltada "apenas para indígenas". Isso acaba fazendo perder de vista a transversalidade que está no espírito do programa da EIB, além de excluir os estudantes migrantes e nãoindígenas. Ainda, ocorre o que a autora chama de isomorfismo, ao serem associadas áreas

14 Para um aprofundamento em questões referentes à EIB no contexto latino-americano, podem ser consultados os trabalhos de Paladino e Czarny (2012) e de Candau e Russo (2010). Sobre as experiências escolares com o quíchua e outras línguas indígenas em contextos urbanos da Argentina, pode-se consultar o material publicado pelo Ministério da Educação: Educación Intercultural Bilingue em Argentina. Sistematización de experiencias (2004) 
indígenas às zonas rurais, por desconhecimento de que normalmente as regiões urbanas são as que concentram maior proporção de povos indígenas, além de uma importante população migrante, que acaba sendo invisibilizada, o que termina gerando formas sutis de discriminação no marco de uma política que se propõe inclusiva (HECHT, 2015).

Após o percurso pelos trabalhos interessados na situação dos alunos falantes de línguas indígenas, em especial do quíchua, surge a seguinte pergunta: os pedagogos e os professores de língua têm as ferramentas teóricas e pedagógicas necessárias para trabalhar com essas realidades? Nos parágrafos a seguir tentaremos dar algumas pistas sobre as ações que poderiam colaborar para repensarmos nossa formação enquanto docentes.

Acreditamos que existem algumas ferramentas válidas para auxiliar os professores a atuar nesses contextos multiculturais, como pessoas críticas que possam receber em suas aulas alunos migrantes ou falantes de línguas indígenas e agir, não pelo viés do preconceito e das etiquetas, mas com base no conhecimento da complexidade resultante do trabalho com as diferenças culturais e linguísticas. Pois, como já foi sinalizado por autores como Beherán (2009), as escolas argentinas buscam atingir a inclusão: todas as pessoas que têm o desejo de se formar são aceitas, mas na prática "são colocadas à margem da possibilidade de serem beneficiárias de um ensino que vise às diferenças” (BEHERÁN, 2009, p. 6, tradução nossa).

Após expostas as ideias, no atual contexto, acreditamos na influência que os estudos sociolinguísticos devem exercer na educação, e que uma das principais premissas desses estudos precisa ser difundida entre os pedagogos, os professores e os futuros docentes. Trata-se da seguinte concepção:

\footnotetext{
A principal influência dos estudos sociolinguísticos para a educação provém da ênfase veemente na premissa de que todas as variedades que compõem a ecologia linguística de uma comunidade, sejam elas línguas distintas ou dialetos de uma ou mais de uma língua, são funcionalmente comparáveis e essencialmente equivalentes. Nenhum deles é inerentemente inferior, e, portanto, seus falantes não podem ser considerados linguística ou culturalmente deficientes (BORTONI RICARDO, 2005, p. 151).
}

Uma vez que consigam ponderar sobre as reflexões delineadas neste texto, os professores poderiam compreender duas questões chave nesse cenário. Uma delas tem a ver com os silêncios e a outra com os silêncios na constituição das situações de interculturalidade. Sobre a primeira questão, é possível dizer que "essa ideia do silêncio não deve ser entendida como o não falar especificamente, mas como toda uma variedade de formas de conduzir-se [os alunos bolivianos e suas famílias], que implica em não estar onde, como e quando a escola quer" (DREIDEMIE, 2010, p. 343, tradução nossa). Por outro lado, pensar nas situações de interculturalidade significa compreendê-las como circunstâncias nas quais dois grupos com identidades diferentes e com distintos posicionamentos na 
sociedade se relacionam e se comunicam produzindo conflitos, negociações, acordos e inumeráveis mal-entendidos (GRIMSON, 1999).

Nessa mesma lógica, Dell Hymes (1996) acentua a importância de cogitar os fatores socioculturais para explicar a atuação linguística das crianças nos diferentes contextos, já que "quando uma criança de uma determinada matriz de desenvolvimento entra em uma situação na qual expectativas comunicativas são definidas em termos de outra matriz, podem ocorrer falhas na percepção e na análise em todos os níveis" (HYMES, 1996, p. 32, tradução nossa). Soma-se a isso, o questionamento do autor a respeito da existência dos supostos ambientes ou contextos homogêneos, isto é, contextos nos quais todas as pessoas que participam da interação tenham as mesmas condições e competências.

Nesse viés, olhar para a produção intelectual realizada no Brasil, no âmbito da Sociolinguística Educacional, implica revisitar os projetos, as vantagens e resultados de propostas desenvolvidas nos distintos lugares do país. Assim, rever a bibliografia e os aportes teóricos sobre o assunto possibilitou imaginar outros tipos de práticas para a Argentina, abrir novas reflexões e autocríticas, dentre outras considerações.

Diante dos argumentos levantados na nossa revisão e a partir das próprias falas dos entrevistados, acreditamos que todo educador deve ser formado para entender não apenas as diferenças, no sentido estrito da palavra, com toda a complexidade que o termo contém; além disso, todo docente precisa conseguir refletir sobre suas próprias práticas e alterá-las, caso necessário. Desse modo, será possível desarticular o preconceito linguístico que tão fortemente tem se instalado tanto na sociedade em geral e nos meios de comunicação, quanto nos âmbitos educativos. Uma mudança na postura poderá possibilitar aos professores ter completa consciência dos riscos que podem derivar dessa forma de preconceito derivada da consideração da língua ou do dialeto dos alunos como algo "errado e nocivo" (CYRANKA, 2014).

Ainda sobre esse aspecto, Sardi tem apontado que:

\begin{abstract}
As práticas educativas e sociais de que um sujeito participa antes, durante e depois de sua experiência escolar, refletem a desigualdade de classes. Esses sujeitos que, em primeiro lugar, sofrem o estigma da pobreza, são considerados sujeitos que possuem carências derivadas do meio do qual procedem as suas famílias e as suas culturas. Isso faz com que expectativas de rendimento escolar sejam predeterminadas: o fracasso escolar desses alunos está marcado por suas falências e por um preconceito construído na instituição escolar que determina a impossibilidade de reverter essa situação (SARDI, 2000, p. 34, tradução nossa).
\end{abstract}

Os professores precisam saber que os alunos podem se resguardar em silêncio porque acreditam que a variedade por meio da qual eles se comunicam não está em consonância com o esperado: "descrendo do valor inerente à variedade linguística de seus alunos, os professores acabam colaborando para que eles também descreiam de sua própria capacidade de se expressar com competência, segundo os padrões esperados" (CYRANKA, 2014, p. 146). 
Ainda, a compreensão da variedade de espanhol e do substrato de língua indígena permitiria aos professores entenderem que alguns traços e particularidades visíveis na variedade falada pelos próprios alunos migrantes ou filhos de migrantes bolivianos são produto das transferências do quíchua para o espanhol (KRASAN et al., 2017). Acompanhar e incorporar os saberes e materiais produzidos pelos especialistas é necessário, para assim "complementar o aprendizado escolar da variedade padrão do espanhol com um reconhecimento do patrimônio linguístico dos estudantes (...) é uma alternativa potente frente à circulação de representações em desvantagens das línguas indígenas e seus falantes" (KRASAN et al., 2017, p. 23, tradução nossa).

Nesse sentido, somar a todas essas reflexões o conceito de pedagogia culturalmente sensível poderia habilitar novas formas de relacionamentos entre os atores que participam do ato educativo. No que toca a essa concepção, Bortoni Ricardo (2003) oferece a seguinte definição:

\footnotetext{
Essa proposta pedagógica consiste num tipo especial de esforço, empreendido pela escola, que pode reduzir as dificuldades de comunicação entre professores e alunos, desenvolvendo assim a confiança e prevenindo a gênese de conflitos que se movem rapidamente além dos malentendidos, evoluindo para o confronto amargo na troca de identidades entre alunos $e$ professores (BORTONI RICARDO, 2003, p.131).
}

Acreditamos que esse confronto, no caso dos alunos e famílias bolivianas, pode e é ainda mais amargo por se tratar de identidades e nacionalidades distanciadas amplamente, com o agravante de todo o peso do estigma que carrega a comunidade boliviana no território argentino. Ponderar sobre a possibilidade de uma pedagogia culturalmente sensível nos casos de situações de contato linguístico como os que apresentamos aqui, implicaria pensar em um esforço por parte dos professores para se interessar e perguntar aos alunos quais são os contextos de procedência deles, conhecer qual é língua materna dos educandos, em que momento da vida deles deu-se o aprendizado o espanhol, quais as práticas comunicativas no contexto familiar dos aprendizes, dentre outras questões.

A revisão de outros trabalhos sobre comunidades escolares com a presença de estudantes procedentes de contextos em que se fala alguma língua indígena tem permitido observar a forma como os discursos que entram na escola são, muitas vezes, iguais àqueles que circulam dentro do que podemos chamar de "senso comum". E o senso comum raramente apresenta uma percepção sobre a língua como um fenômeno heterogêneo que abriga grande variação e está em constante mudança. Ainda, a partir dessa visão se "folcloriza" a variação regional, se demoniza a variação social, fazendo com que as mudanças sejam interpretadas como sinais de degeneração da língua (STAHL ZILLES; FARACO, 2015).

Por fim, a língua resulta como sendo um forte elemento de discriminação social no próprio contexto escolar, assim como em outros contextos sociais diferentes. Conhecer, 
olhar criticamente e refletir sobre os discursos que circulam sobre a(s) língua(s) e a(s) variedade(s) que convivem nas escolas é uma tarefa que diz respeito a todos - não só a professores de língua, mas a todos os educadores, independentemente de sua área de atuação -, se considerarmos que nossas ações impactam diretamente nas trajetórias pedagógicas dos estudantes.

\section{CONCLUSÃO}

Até aqui, o panorama sobre os sentidos dos silêncios a partir dos diferentes textos e pesquisas desenvolvidas na Argentina evidenciou aspectos tais como: as representações e os estereótipos que os professores constroem sobre a coletividade boliviana, os estigmas que pesam sobre os alunos bolivianos na sala de aula, o modo como o bilinguismo é percebido pelos docentes e, principalmente, pelos alunos.

A incorporação dos aportes da Sociolinguística Educacional na revisão da fala dos bolivianos possibilitou a formulação de questões que apontam para aspectos além dos evidenciados nos trabalhos já realizados e permitiu a interpretação de que os silêncios podem ser resultado de uma resposta a operações de estigmatização e/ou um produto da insegurança linguística propiciada por práticas equivocadas em sala de aula.

Da mesma forma, percebemos que a insegurança também pode ser produto do valor que os bolivianos e seus filhos, muitos deles falantes de quíchua que ingressam nas escolas argentinas, conferem à sua variedade de espanhol. Ademais, os julgamentos sobre a competência de um falante de uma língua que não é a língua materna dele contribuem para as formas de insegurança linguística que podem ser manifestadas no discurso.

Diante do exposto, oferecemos alguns caminhos possíveis para repensar a formação dos professores em aspectos pontuais, tais como: a abordagem de conhecimentos voltados para questões de bilinguismo, a apresentação de materiais que auxiliem no conhecimento sobre as particularidades da variedade do espanhol com substrato indígena e, por fim, os conceitos da pedagogia culturalmente sensível que poderiam ajudar a olhar a problemática a partir de um outro ponto de vista, abrindo possibilidades para novas reflexões.

\section{REFERÊNCIAS}

ARGENTINA- MINISTERIO DE EDUCACIÓN, CIENCIA Y TECNOLOGÍA. Educación Intercultural Bilingüe en Argentina $1^{a}$. ed. - Buenos Aires: Ministerio de Educación, Ciencia y Tecnología, 2004.

APPEL, René; MUYSKEN, Pieter. Bilingüismo y contacto de lenguas. Barcelona: Ariel, 1996. 
BEHERÁN, Mariana. Niños, niñas y jóvenes bolivianos y bolivianas en la ciudad de Buenos Aires. Escolaridad y experiencias formativas. Estudios Migratorios Latinoamericanos CEMLA, n.67, p. 375-396, 2009.

BORTON, Laureano. Representaciones docentes sobre los niños tobas y sobre el silencio en una escuela en situación de interculturalidad. In: NOVARO, Gabriela. (Coord.) La interculturalidad en debate. Buenos Aires: Editorial Biblos, 2011, p. 85-104

BORTONI-RICARDO Stella Maris. Processos Interativos em sala de aula e a pedagogia culturalmente sensível. Polifonia(UFMT), Cuiabá-MT, v. 01, n. 07, p. 119-136, 2003.

BORTONI-RICARDO, Stella Maris. Nós cheguemu na escola, e agora? Sociolinguística na sala de aula. São Paulo: Parábola Editorial, 2005

BOURDIEU, Pierre. ¿Qué significa hablar? Economía de los intercambios lingüísticos. Madrid: Akal, 1985.

CALVET, Louis Jean. Sociolinguística. uma introdução crítica. Trad. Marcos Marcionilo. 4ta ed. São Paulo: Parábola, $2002[1942]$

COURTIS, Corina; PACECCA, María Inés. Diagnóstico participativo sobre discriminación: historia, hallazgos, reflexiones. In: IX Congreso Argentino de Antropología Social, 2008, Posadas. Actas [...]. Posadas: Universidad Nacional de Misiones. p. 1-12.

CYRANKA, Lucia. Avaliação das variantes: atitudes e crenças em sala de aula. In: MARTINS, Marco Antônio; VIEIRA, Silvia Rodrigues; TAVARES, Maria Alice (Org.). Ensino de português e Sociolinguística. São Paulo: Contexto, 2014, p. 133-156.

DOMENECH, Eduardo. "Bolivianos" en la "escuela argentina": Representaciones acerca de los hijos de inmigrantes bolivianos en una escuela de la periferia urbana. REMHU-Revista Interdisciplinar da Mobilidade Humana, v. 22, n.42, p. 171-188, 2014

DREIDEMIE, Patricia. Nosotros lo hablamos mezclado: Estudio etnolingüístico del quechua hablado por migrantes bolivianos en Buenos Aires (Argentina). 394 p. Tese (Doctorado)- Facultad de Filosofía y Letras, Universidad de Buenos Aires, Buenos Aires, 2010

FERRÃO CANDAU, Vera Maria; RUSSO, Kelly. Interculturalidade e Educação na América Latina: uma construção plural, original e complexa. Revista Diálogo Educacional, Curitiba, v. 10, n. 29, p. 151-169, 2010.

FLEURI, Reinaldo Matias. Políticas da diferença: para além dos estereótipos na prática educacional. Educação \& Sociedade, vol.27 no.95. p. 495-520, 2006. http://dx.doi.org/10.1590/S0101-73302006000200009

GANDULFO, Carolina. Entiendo pero no hablo: el guaraní "acorrentinado" en una escuela rural: usos y significaciones. Buenos Aires: Antropofagia, 2007.

GARZÓN LÓPEZ, Pedro. Pueblos indígenas y decolonialidad. Sobre la colonización epistemológica occidental. Andamios, v.10, n. 22, p. 305-331, 2013.

GRIMSON, Alejandro. Relatos de la diferencia y la igualdad. Buenos Aires: EUDEBA, 1999

GUBER, Rosana. La etnografía, método, campo y reflexividad. Bogotá: Grupo Editorial Norma, 2001.

HECHT, Ana Carolina. Encrucijadas de significados acerca de la relación lengua e identidad en niños indígenas en contextos urbanos. A/teridades, n. 18, p. 143-157, 2008.

HECHT, Ana Carolina. Educación intercultural bilingüe en Argentina: un panorama actual. Ciencia e Interculturalidad, v. XVI, p. 20-30, 2015

HENTSCHEL, Jurek. "En mí ya termina el quechua". Aproximaciones al uso lingüístico de hablantes bilingües (quechua-castellano) en el área urbana de Cochabamba, Bolivia. Indiana, vol. 33, núm. 1, p. 109-131, 2016.

HYMES, Dell. Acerca de la competencia comunicativa. Traducción de Juan Gómez Bernal. Santa Fe de Bogotá: Universidad Nacional de Colombia, p. 13-37, 1996. Título original: On Communicative Competence.

KOHATSU, Lineu Norio. Imigração, assimilação e xenofobia: algumas notas. Cadernos CERU, 30(1), p. 50-75, 2019. 
KRASAN, Marta; AUDISIO, Cynthia; JUANATEY, Mayra; KROJZL, Juan; RODRÍGUEZ, Marina. Material de consulta para el docente en contextos de diversidad lingüistica: estructuras contrastivas guarani-español, quechua-español | KRASAN, Marta... [et al.]; supervisión de GOLLUSCIO, Lucía; CICCONE, Florencia - 1a ed . - Ciudad Autónoma de Buenos Aires: Editorial de la Facultad de Filosofía y Letras Universidad de Buenos Aires, 2017. Disponível em: http://publicaciones.filo.uba.ar/sites/publicaciones.filo.uba.ar/files/Material\%20de\%20consulta\%20para\%20el\%20d ocente\%20en\%20 contextos\%20de\%20diversidad\%20ling\%C3\%BC\%C3\%ADstica_interactivo_0.pdf. Acesso em: 18 fev. 2021.

MARTíNEZ, Laura. Niños migrantes y procesos de identificación en el contexto escolar: "no se animan a contar". Algunas aproximaciones al análisis de la vergüenza. Revista Latinoamericana de Educación Inclusiva, v. 6, n.1, p. 7388, 2012.

NARVAJA DE ARNOUX, Elvira; BEIN, Roberto. Políticas lingüísticas y enseñanza de lenguas. Buenos Aires: Editorial Biblos, 2015

NOVARO, Gabriela. Palabras desoídas - palabras silenciadas - palabras traducidas: voces y silencios de niños bolivianos en escuelas de Buenos Aires. Educação, v. 34, p. 47-64, 2009.

OBSERVATORIO DE LOS DERECHOS DE LOS PUEBLOS INDÍGENAS Y CAMPESINOS. Unas 700.000 personas mantienen vivas 15 lenguas indigenas en Argentina. Buenos Aires: UNICEN, 2019. Disponível em:

https://www.soc.unicen.edu.ar/observatorio/index.php/22-articulos/106-unas-700-000-personas-mantienen-vivas15-lenguas-indigenas-en-argentina. Acesso em: 20 maio 2021.

ORLANDI, Eni Puccinelli. Terra à vista. Discurso do confronto: Velho e Novo Mundo. 2da Ed, Campinas: Editora da UNICAMP, 2008

ORLANDI, Eni Puccinelli. As formas do silêncio no movimento dos sentidos. Campinas: Editora da UNICAMP, 1992.

ORLANDI, Eni Puccinelli. Algumas considerações discursivas sobre a educação indígena. Em aberto, Brasília, ano 3 , n. 21, abr./jun, p. 20-29, 1984

PACCECA, María Inés; COURTIS, Corina. "Con la cara que tenés, estás en el horno". Migración boliviana y discriminación. Estudios Migratorios Latinoamericanos Nº67, p. 397-416, 2009

PALADINO, Mariana; CZARNY, Gabriela (orgs.) Povos indígenas e escolarização. Discussões para se repensar novas epistemes nas sociedades latino-americanas. Rio de Janeiro: Garamond, 2012.

PÉREZ, Liliana; ROGIERI, Patricia. Lengua nacional y lengua de inmigración en la política lingüística. Argentina (18801930). Revista Digital de Políticas Lingüísticas. v. 5, n. 5, p. 99-117, 2013.

RUBIN, Joan. National bilingualism in Paraguay. The Hague: Mouton, 1968.

SARDI D’ARIELLI, Valeria. La sociolingüística: un arma contra el fracaso escolar. Enseñanza de la lengua, UBA, Facultad de Filosofía y Letras, p. 33-41. Ficha de cátedra. 2000.

SOARES, Magda. Linguagem e escola, uma perspectiva social. São Paulo, SP: Ática, 2002.

STAHL ZILLES, Ana Maria; FARACO, Carlos. Pedagogia da variação linguística. São Paulo: Parábola Editorial, 2015.

TORANZOS, Romina. Mantenimiento y cambio de lengua: el quechua entre inmigrantes bolivianos residentes en Bahía Blanca. 62 p. Tesina (Licenciatura en Letras) Departamento de Humanidades, Universidad Nacional del Sur, Bahía Blanca, 2014

UNICEF; FUNPROEIB ANDES. Atlas sociolingüístico de pueblos indígenas en América Latina. Cochabamba: FUNPROEIB Andes, 2009

XENOFOBIA. In.: Dicio, Dicionário Online de Português. Disponível em: https://www.dicio.com.br/xenofobia/ Acesso em: 15 de maio de 2021. 